\title{
Analysis of Scientific and Information Needs of Medical Specialists in the Information and Documentary Support of the Medical Industry
}

\author{
Tymoshenko Innessa \\ Open International University of Human Development "Ukraine" \\ Vasylkiv College
}

\begin{abstract}
The article analyzes the specificity and diversity of information needs of medical professionals and professional orientation to the communicative needs of the target scientific groups. The author raises questions about the difficulties of using innovative medical technologies in clinical practice of national healthcare, which need to be overcome by an appropriate system of their information support. The author identifies the main features of professional scientific needs, which are important for the organization of information and documentation support of the activities of organizations and individual medical professionals. Presented the factors that shape the information needs and search behavior of the user. The analysis uses the classification of scientific and information needs of the medical user, which was developed by a national scientist A. R. Uvarenko. New scientific areas are offered to study information needs and expand the range of services.
\end{abstract}

Keywords: scientific and information needs, sources of medical information, documentation, users of information.

Актуальність досліджсеня. У контексті нашого дослідження ми зупинимося на розгляді формування та задоволення науково-інформаційних потреб медичних фахівців та інших користувачів. Науково-інформаційна діяльність завжди підпорядкована єдиній меті - задоволенню інформаційної потреби науковців та інших користувачів $[2 ; 4 ; 5 ; 6 ; 14 ; 15 ; 16]$, саме тому знання цієї інформаційної категорії, певно, визначає успіх наукової комунікації в реалізації будь-якої форми обслуговування певного користувача. Іншими словами, ефективне використання науково-інформаційних ресурсів неможливе без належних знань науковоінформаційної потреби.

Виклад основного матеріалу. Саме поняття «інформаційна потреба» визначається як потреба особистості (групи людей) в інформації. Насправді під час вирішення управлінських і науково-технічних завдань фахівці відчувають необхідність здобути нові знання, а інформація постає лише як проміжна форма його ланки. 
Інформаційні потреби будуть задоволені тільки в тому разі, коли через інформаційне повідомлення (документні або усні) знання автора (авторів) перетворяться на знання користувачів.

Отже, формування інформаційної потреби користувача залежить від багатьох чинників, різноманітних за своєю природою. Для органів науково-технічної інформації, призначення яких саме в інформаційному забезпеченні наукової діяльності, поглиблення в комунікаційну типізацію виглядає зайвим теоретизуванням. Але для наукової інформатики таке теоретизування не тільки не зайве, але просто необхідне, інакше теорія інформаційних потреб зводиться до узагальнення емпіричного досвіду, і не більш того.

Ще в 70-80-ті pp. Е. С. Бернштейном була запропонована ідея «парадигми, що радить» інформаційного сервісу, яка по суті спрямована на перехід від задоволення потреб, характерного для «обслуговуючої парадигми», до орієнтації на абсолютні комунікаційні потреби цільових наукових груп. За даною парадигмою інформаційні служби вирішують завдання не просто знайти в інформаційно-бібліотечних фондах «готове рішення», а оцінити можливість його отримання при сучасному рівні суспільного знання і вказати фахівцям шлях (що і як потрібно робити) для отримання бажаного результату.

Саме тому треба враховувати специфічність інформаційної потреби медичного фахівця, які різноманітні і не обмежуються необхідністю отримання конкретних медичних відомостей, але потрібні і рекомендації, діагностичні та лікувальні методи, нові ліки, та ін.

Більшість медичних фахівців за даними [7, с. 3-6], вважають проблему отримання інформації найскладнішою частиною своєї роботи: вони не в змозі опрацювати існуючий обсяг наукової інформації, не встигають стежити за новою літературою, не мають навиків працювати з нею, адекватно оцінювати їі, не знають останніх досягнень медицини і біології. Майже третину свого часу американський лікар проводить за збором інформації.

Потреба в інформації виникає у медичного фахівця при кожній взаємодії 3 хворим, причому об'єктивно оцінюваний рівень потреб вищий, ніж той, що визначають самі користувачі. Багато питань, що виникають у медичного фахівця, стосуються 
методів лікування і призначення лікарських засобів. Часто - це складні, різноаспектні питання [13, с. 46].

Медичні користувачі можуть користуватися різноманітними джерелами медичної інформації, формальними і неформальними, первинними (журнальні статті) i вторинними (довідниками, оглядами, клінічними рекомендаціями, реферативними виданнями). Згідно з даними опитувань, для медичних фахівців особливу роль мають неформальні джерела особистого спілкування 3 колегами. Цікаво, що виявлена розбіжність між суб'єктивними уявленнями медичного фахівця про джерела інформації, що використовуються ними під час прийому хворих, і об'єктивною ситуацією. Більшість 3 них вважає, що найчастіше вони використовують друкарські видання на папері (на першому місці - довідники, зокрема фармацевтичні, потім журнали), тоді як насправді більше ніж у половині випадків джерела інформації були неформальними - консультації колег (у першу чергу лікарів вузької спеціалізації, потім — фармацевтів).

Користувачів медичної інформації можна поділити на декілька категорій: 1) вчені-дослідники (зацікавлені переважно в біомедичній інформації); 2) клініцисти і практичні лікарі (зацікавлені перш за все в клінічній інформації); 3) менеджери (організатори) охорони здоров'я (зацікавлені в законодавчій, управлінській, комерційній та іншій інформації); 4) студенти медичних закладів (зацікавлені в науково-методичній інформації, оглядовій з клінічної медицини). Головна відмінність в інформаційній поведінці учених і клініцистів полягає в тому, що вчені вважають за краще працювати 3 джерелом інформації: особисто читати наукові документи, розмовляти $з$ колегами, тоді як клініцисти хочуть одержувати потрібні їм відомості через посередника, який знайде ці відомості в літературі і надасть їх у зручній формі в потрібний час. Інформаційні потреби вчених зазвичай мають проблемно-тематичний, тобто загальніший, характер, а інформаційні потреби клініцистів набагато конкретніші.

Потреби користувачів клінічної інформації зумовлені, в першу чергу, специфікою і якісними характеристиками необхідної їм інформації.

Складне становище медиків посилюються ускладненим доступом до світових джерел інформації. Залишаються деякі перешкоди, як от: 1) відсутність у бібліотеках 
засобів на забезпечення доступу до наукових видань за комерційною моделлю їх придбання; 2) недостатній розвиток телекомунікаційної інфраструктури; 3) незнання лікарями англійської мови.

Крім того, висока завантаженість клінічною роботою не залишає часу і сил на регулярне вивчення первинних джерел. Ситуація така, що пошук інформації і вивчення спеціальної літератури не обмежується основною професійною діяльністю медика.

Утім, в усьому світі лікарі розуміють, що знання останніх досягнень медицини, критичний аналіз і уміння порівняти отримане з літератури 3 конкретною клінічною ситуацією - необхідні передумови ухвалення правильних клінічних рішень.

Класифікацію науково-інформаційної потреби медичного користувача здійснив А. Р. Уваренко, який виходив з прикладного сенсу їх формування [3, с. 168; 10, с. 96]. Перша потреба обмежена динамікою, високою стабільністю за тематикою та низькою вибірковістю. Друга потреба характеризується підвищеною вибірковістю та високою стабільністю. Третя - високою динамікою, мінімальною стабільністю та високою вибірковістю.

Зрозуміло, що задоволення науково-інформаційної потреби користувачів, які умовно належать до першої групи, не потребує значних затрат сил, ресурсів, часу тощо, як задоволення інформаційних потреб користувачів третьої групи.

Мабуть, з цієї причини науково-інформаційне забезпечення лікаря-практика i складна проблема, котра вирішується у вітчизняній охороні здоров'я поки що незадовільно. Тобто використання медичних інноваційних технологій у клінічній практиці вітчизняної охорони здоров'я має значні труднощі, подолання яких потребує відповідної системи їх інформаційного забезпечення. Через що, основною ознакою професійних наукових потреб, яка має значення для організації інформаційного забезпечення діяльності організації і окремих фахівців, є тематика та наочна сфера, правильне визначення яких має значний вплив на ефективність задоволення інформаційної потреби.

3 однієї і тієї ж тематики різним користувачам можуть виявитися необхідними абсолютно різні відомості. Тому іншою важливою ознакою інформаційних потреб є характер необхідної інформації. 
3 цієї точки зору розрізняють відомості, що відображають результати:

- теоретичних і експериментальних досліджень;

• проектних і дослідно-конструкторських розробок;

- випробування і контролю якості;

- упровадження нового устаткування або технології;

- експлуатації, модернізації і ремонту устаткування;

- маркетингових досліджень ринку і діяльності фірм-конкурентів тощо.

Також для медичної галузі з урахуванням видової специфіки одержуваних відомостей можна додати: 1) клінічні випробування; 2) рандомізовані контрольовані дослідження; 3) клінічні випадки; 4) контрольовані клінічні дослідження; 5) багатоцентрові дослідження та ін.

Для організації документаційного забезпечення важливими є час виникнення i період дії потреб. За часом виникнення розрізняють стабільні, тобто вже відомі, виявлені раніше потреби, і нові, ті, що тільки виникли. За періодом дії - разові, що зникають після їх задоволення, і потреби тривалої дії, які потребують систематичного надання необхідної інформації.

Перш за все, важливо визначити, для здійснення якої діяльності потрібна інформація і наскільки новою ця наочна сфера є для користувача. Інакше кажучи, встановлюється збіг тематики інформаційних потреб з базовою освітою користувачів, досвідом роботи в цьому напрямі. 3 цих позицій розрізняють профільні потреби; потреби в інформації по суміжних галузях або проблемах; потреби в інформації з тих галузей знання або суспільної практики, які індивідові раніше не траплялися.

Профільність інформаційних потреб визначають критерії відбору документів і ступінь докладності інформації, що надається користувачам. При задоволенні потреб за основним профілем діяльності можуть пропонуватися джерела підвищеної складності.

Таким чином, для раціональної організації документаційного забезпечення необхідний систематичний i багатоаспектний аналіз інформаційних потреб, коректованих даними зворотного зв'язку — оцінкою користувачами якості послуг, що надаються. 
Щодо методології вивчення інформаційних потреб, то традиційно потреби своїх читачів почали вивчати бібліотеки, використовуючи при цьому статистичні показники: кількість читачів; кількість відвідувань; обсяг книговидачі та ін. Аналізувалися і соціально-демографічні характеристики читачів: стать, вік, соціальний стан, освіта, сфера діяльності та ін., що дозволяло реалізувати «принцип диференційованого підходу» до користувачів бібліотеки. Суть цього принципу в тому, що вплив книги зростає, якщо вона адресується не читачеві взагалі, а певній людині, максимально відповідає його читацькій підготовці, потребам й інтересам [9, с. 44].

Крім опитування, провідним дослідницьким методом вивчення потреб читачів вважається метод аналізу читацьких формулярів, який дозволяє виявити тематику запитів і типово-видову картину читання. У 70-х рp. ХХ ст. вивчення читачів сприймалося як загальнодержавна проблема, яка вирішувалася проведенням глобальних соціологічних досліджень.

Водночас у сфері науково-інформаційної діяльності активно розвивався новий науковий напрям, спрямований на вивчення інформаційних потреб. Практикам обслуговування збагатила методами виявлення i характеристики інформаційних потреб, а також уточнення невизначених інформаційних запитів [11, с. 4]. Встановлено відомості, необхідні і достатні для опису інформаційних потреб: тематика, характер інформації, збіг тематики потреб з базовою освітою і профілем попередньої діяльності фахівця; час виникнення потреб і їх стабільність, що визначає підготовленість фахівця до сприйняття нової інформації; місце абонента в системі організаційної комунікації (експерт, інформаційний лідер та ін.) [8, с. 392].

До середини 60-х рр. основна увага в розробці проблеми приділялася спрямованості потреб на конкретні види джерел отримання інформації (первинні і вторинні, опубліковані і неопубліковані та ін.) і допомоги, що надається вченим і фахівцям інформаційними підрозділами і бібліотеками. Найяскравіше виявилося послідовне поєднання аналізу потреб в інформації з вивченням стану їх задоволення.

3 поглибленням уявлень про потреби принципово змінювалася процедура вибору режиму і форми обслуговування. Спочатку обслуговування починалося 3 моменту надходження запиту і (або) закінчувалося на стадії його задоволення, або продовжувалося, тобто переходило в поточний режим. 
Вивчення механізму виникнення інформаційної потреби у зв'язку з змістом і етапами наукової діяльності фахівців, а також специфікою вирішуваних ними завдань сприяло формуванню нових уявлень. Виникло і почало використовуватися службами інформації наукових та учбових закладів випереджаюче обслуговування, що припускає інформаційний супровід планів НДР. Пізніше, 3 розвитком методів аналітико-синтетичної переробки інформації, набуло поширення інформаційне забезпечення науковців, розроблені його концептуальні основи у системі охорони здоров'я, зокрема медичної науки.

3 поглибленим вивченням інформаційних потреб і розширенням асортименту послуг прийшло нове розуміння ефективності обслуговування. Спочатку основним інструментом вивчення задоволеності користувачів був аналіз відмов на літературу, яку вони запитували. Пізніше виникла проблема тематичної відповідності інформаційних потреб, інформаційних запитів і результатів інформаційного обслуговування. Карти зворотного зв'язку стали обов'язковим елементом окремих видів послуг, наприклад, вибіркового розповсюдження інформації.

Цей екскурс в історію вивчення користувачів дозволяє простежити тенденцію поглиблення інтересу до потреб окремої особистості. Об'єктом вивчення спочатку були великі соціальні групи (робітники, жителі сіла), потім вивчалися інформаційні потреби окремих професійних груп (медиків, учителів, учених), - інформаційна поведінка кожної конкретної особистості.

Кількість чинників, що формують нині інформаційні потреби і пошукову поведінку користувачів, значна, причому багато з них раніше взагалі не бралися до уваги бібліотечними фахівцями. Наприклад, чинник консервативності користувачів інформації, який виявляється в тому, що, опанувавши будь-яку систему або програму, користувачі інформації з великим небажанням застосовують вперше нові прийоми пошуку чи подання матеріалу [12, с. 58]. Тому впровадження електронних i телекомунікаційних зв'язків у систему наукових комунікацій не зумовлює істотні зміни в пошуковій поведінці користувачів. У будь-якому разі поведінкові характеристики залишаються досить стійкими: користувачі наукової інформації продовжують сприймати бібліотеку як соціокультурний, а не інформаційний центр. 
Процес переробки інформації дослідником характеризується не тільки визначеністю (знайти готові рішення, оцінити рівень виконаних досліджень та ін.), але й пошуком, формуванням, створенням власного рішення [1, с. 304].

Можна також припустити, що на вибір каналів надання інформації і документів впливають особливості сприйняття друкованих текстів і текстів, на електронних носіях. Спостереження бібліотечних фахівців свідчать: коли читання наукової літератури є невід'ємною частиною творчої діяльності, перехід від навиків сприйняття друкарських текстів до електронних здійснюється складніше, ніж при читанні «ділової літератури» (довідкових й інформаційних видань, підручників, практичного керівництва). Очевидно, наукові документи мають інше смислове, емоційне, психологічне і тимчасове навантаження, ніж тексти документів для ділового читання.

Виявлення інформаційних потреб фахівців установ є обов'язковою функцією служби інформації незалежно від іiі штатних можливостей. Тільки знання тематики професійних потреб і характеру відомостей, необхідних користувачам, дозволяє ефективно здійснювати всі інші напрями інформаційної роботи.

Висновки. Підсумовуючи викладене вище, можна стверджувати, що вивчення потреб користувачів спрямовується на виявлення і аналіз їх професійних відмінностей. Для інформаційних служб це означає, що вивчатися повинні не тільки інформаційні потреби та інформаційна поведінка, але й вимоги користувачів (споживацькі переваги) як до інформаційної продукції, так і до комфортності в цілому.

\section{References}

1. Bregneva V. V., Mynkyna V. A. Informacyonnoe obslugyvanye: produkty y uslugy, predostavlyaemye byblyotekamy y slugbamy informacyy predpryyatyy [Information services: products and services provided by libraries and enterprise of services' information.] SPb.: Profesiya, 2004. 304 p.

2. Matviyenko O. Tsinnisno-prahmatychni konteksty informatsiynoyi kul'tury osobystosti [Value-pragmatic contexts of information culture of personality]. Ridna shkola. 2004. No. 10. P. 13-15.

3. Neuchnaya medycynskaya informacyya $v$ dokumental'nyh potokah [Scientific medical information in documentary streams] / pod red. A. R. Uvarenko. Kyiv: Zdorovya, 1988. $168 \mathrm{p}$.

4. Pet'ko L. V. Vyklyky KHKHI stolittya dlya osvitn'oho prostoru Ukrayiny [The challenges of educational space in the 21-st century]. Naukovi pratsi [Chornomors'koho 
derzhavnoho universytetu imeni Petra Mohyly kompleksu "Kyyevo-Mohylyans'ka akademiya"]. Seriya : Pedahohika : nauk. zhurn. / Chornom. derzh. un-t imeni Petra Mohyly; red. kol. : O. P. Meshchaninov (holova) [ta in.]. Mykolayiv: Vyd-vo CHNU imeni Petra Mohyly, 2017. Vol. 303. Issue 291. P. 10-14.

5. Pet'ko L. V. Informatsiyno-navchalne seredovische yak umova formuvannya profesiyno orientovanogo inshomovnogo navchalnogo seredovischa v umovah universitetu [Information and teaching environment as a condition of professionally oriented foreign language teaching environments formation in the terms of the university] // Informatsiyni tehnologiyi u profesiyniy diyalnosti: Tr. IX Vseukrayinskoyi nauk.-prakt. konf., Ryvnenskiy derzhavniy gumanytarniy un-t (25 bereznya 2015 r.) Ryvne, 2015. P. 89-91.

6. Pet'ko L. V. Filosofs'ko-lingvistychni idei' rozuminnja mizhljuds'koi' komunikacii' u social'nomu seredovyshhi [Philosophical and linguistic ideas of interpersonality communication in professional sphere]. Naukovi zapysky NaUOA. - Ostrog: Vyd-vo «Ostroz'ka akademija», 2015. Serija «Filologichna». Issue 53. P. 353-356.

7. Rozenfel'd L. G., Uvarenko A. R., Volosovets' O. P. Aktual'ny problemy suchasnogo medychnogo naukoznavstva [Actual problems of basic medical science] // problemy suchasnogo medychnogo zakonodavstva: mater. nauk.-prakt. konf., 18-19 travnya 2006 p. Ternopil, 2006. P. 3-6.

8. Socyal'nye komunykacyy (teoryya, metodologyya, deyatel'nost'): slovarspravochnyk [Social communications (theory, methodology, activity): dictionary]. Kxarkiv: KP «Gorodskaya typografyya» 2009. 392 p.

9. Spravochnyk informacyonnogo rabotnyka [Information Worker's Handbook] / Nauch. red. R. S. Gylyarevskyy, V. A. Mynkyna. - SPb.: Professyya, 2005. 552 p.

10. Uvarenko A. R. Korotko pro suchsne uyavlennya perebudovy ohorony zdorov'ya v Ukrayni [Shortly about contemporary representation of health care restructuring in Ukraine] // Problema efektyvnosty vycorystannya naukovyh informacyynyh resursyv $\mathrm{v}$ ohorony zdorov'ya ta ynshy problem ukraynskogo nauroznavstva: mater. nauk.-prakt. konf. (24-25 travnya 2007 p.), m. Ivano-Frankivs'k. Kyiv, 2007. P. 93-96.

11. Cheban V. I. Perspektyvy rozvytku centru naukovo-medychnoy informacyy v galuzu yak providnoy degavnoy ustanovy [Prospect for the development of the center of science medical information of the sovereign state] // Problema efectyvnosty vycorystannya naukovyh informacyqnyh resursyv $\mathrm{v}$ ohorony zdorov'ya ta inshi problemy medychnogo naukoznavstva: mater. nauk.-prakt. konf. (24-25 travnya 2007 p.), m. Ivano-Frankivs'k. Kyiv, 2007. P. 100-101.

12. Sharabchiev U. T., Heyfec N. E., Moskvycheva T. N. Resursy Internet dlya rabotnykov praktycheskogo zdravohranenyya [INTERNET Resources for Practical Healthcare Workers]. Voprosy organyzacyy zdravohranenyya. 1999. No 1. P. 56-58.

13. Shahmatova T. B., Tymonyn A. N. Innovacyonnaya deyatal'nost' $i$ medycyna [Innovations and medicine]. Patenty i lycenzyy. 2005. No. 3. P. 46-49.

14. Bodnarchuk, O., Bodnarchuk, O., Ersozoglu, R., Kanishevska, L., Pet'ko, L., Turchynova, G., \& Vyshnivska, N. (2019). Model of Entrepreneurial Corporate Education and Prospects of Professional Development of Managers in Ukraine. Journal of 
Entrepreneurship Education, 22(2).

15. Sabat, N., Ersozoglu, R., Kanishevska, L., Pet'ko, L., Spivak, Y., Turchynova, G., \& Chernukha, N. (2019). Staff development as a condition for sustainable development entrepreneurship. Journal of Entrepreneurship Education, 22(1S)

16. Ternopilska V. I., Andruschenko V. I. Features of Formation of Future RadioElectronic Specialists' Technical Competence. Intellectual Archive. 2015. Volume 4. No. 6 (November). - Toronto : Shiny Word Corp., Canada. PP. 114-119.

\section{Translation of the Title, Abstract and References to the Author's Language}

\section{УДК 651:010'5}

Тимошенко Інесса. Аналіз науково-інформаційних потреб медичних фахівців при інформаційно-документальному забезпеченні медичної галузі.

У статті аналізуються специфічність та різноманітність інформаційних потреб медичних фахівців і професійної орієнтації на комунікативні потреби цільових наукових груп. Автором піднімаються питання про труднощі використання медичних інноваційних технологій у клінічній практиці вітчизняної охорони здоров'я, подолання яких потребує відповідної системи їх інформаційного забезпечення. Визначено основні ознаки професійних наукових потреб, які мають значення для організації інформаційно-документаційного забезпечення діяльності організацій i окремих медичних фахівців, визначені чинники, що формують інформаційні потреби i пошукову поведінку користувача. Для аналізу використовується класифікація науковоінформаційних потреб медичного користувача, яка була розроблена вітчизняним вченим А. Р. Уваренком. Пропонуються нові наукові напрями, спрямовані на вивчення інформаційних потреб і розширення асортименту послуг.

Ключові слова: науково-інформаційні потреби, джерела медичної інформації, документаційне забезпечення, користувачі інформації.

Тимошенко Инесса. Анализ научно-информационных потребностей медицинских специалистов при информационно-документальном обеспечении медицинской отрасли.

В статье анализируются специфика и разнообразие информационных потребностей медицинских специалистов и профессиональной ориентации на коммуникативные потребности целевых научных групп. Автором поднимаются вопросы о трудностях использования медицинских инновационных технологий в клинической практике отечественного здравоохранения, преодоление которых требует соответствующей системы их информационного обеспечения. Определены основные признаки профессиональных научных потребностей, которые имеют значение для организации информационно-документационного обеспечения деятельности организаций и отдельных медицинских специалистов, описаны факторы, формирующие информационные потребности и поисковое поведение пользователя. Для анализа используется классификация научно-информационных потребностей медицинского пользователя, разработанная отечественным ученым А. Р. Уваренко. Представлены новые научные направления, направленные на изучение 
информационных потребностей и расширения ассортимента услуг.

Ключевые слова: научно-информационные потребности, источники медицинской информации, документационное обеспечение, пользователи информации.

\section{Jimepamypa}

1. Брежнева В. В., Минкина В. А. Информационное обслуживание: продукты и услуги, предоставляемые библиотеками и службами информации предприятий. СПб.: Профессия, 2004. 304 с.

2. Матвієнко О. Ціннісно-прагматичні контексти інформаційної культури особистості. Рідна школа. 2004. № 10. С. 13-15.

3. Научная медицинская информация в документальных потоках / под ред. А. Р. Уваренко. - Київ: Здоров'я, 1988. - 168 с.

4. Петько Л. В. Виклики XXI століття для освітнього простору України. Наукові праиі [Чорноморського державного університету імені Петра Могили комплексу "Києво-Могилянська академія"]. Серія : Педагогіка : наук. журн. / Чорном. держ. ун-т імені Петра Могили; ред. кол. : О. П. Мещанінов (голова) [та ін.]. Миколаїв : Вид-во ЧНУ імені Петра Могили, 2017. Т. 303. Вип. 291. С. 10-14.

5. Петько Л. В. Інформаційно-навчальне середовище як умова формування професійно орієнтованого іншомовного навчального середовища в умовах університету // Інформаційні технології у професійній діяльності: тр. IX Всеукраїнської наук.практ. конф., Рівненський державний гуманітарний ун-т, 25 березня 2015 р. Рівне, 2015. С. 89-91.

6. Петько Л. В. Філософсько-лінгвістичні ідеї розуміння міжлюдської комунікації у соціальному середовищі. Наукові записки Наџіонального університету «Острозька академія». Серія «Філологічна» : зб. наук. праць / укл. І. В. Ковальчук, Л. М. Коцюк, С. М. Новоселецька. Острог: Вид-во Національного ун-ту «Острозька академія», 2015. Вип. 53. С. 309-312.

7. Розенфельд Л. Г., Уваренко А.Р., Волоконець О. П. Актуальні проблеми сучасного медичного наукознавства // Проблеми сучасного медичного наукознавства: матер. наук.-практ. конф. (18-19 травня 2006 р.). Тернопіль, 2006. С. 3-6.

8. Социальные коммуникации (теория, методология, деятельность): словарьсправочник. Харьков: КП «Городская типография» 2009. 392 с.

9. Справочник информационного работника / науч. ред. Р.С. Гиляревский, В. А. Минкина. - СПб.: Профессия, 2005. 552 с.

10. Уваренко А. Р. Коротко про сучасне уявлення перебудови охорони здоров'я в Україні // Проблема ефективності використання наукових інформаційних ресурсів в охороні здоров'я та інші проблеми медичного наукознавства: матер. наук.-практ. конф. (м. Івано-Франківськ, 24-25 травня 2007 р.,). Київ, 2007. С. 93-96.

11. Чебан В. І. Перспективи розвитку центру наукової медичної інформації в галузі як провідної державної установи // Проблема ефективності використання наукових інформаційних ресурсів в охороні здоров'я та інші проблеми медичного 
наукознавства: матер. наук.-практ. конф. (24-25 травня 2007 р.), м. Івано-Франківськ. Київ, 2007. С. 100-101.

12. Шарабчиев Ю. Т., Хейфец Н. Е., Москвичева Т. Н. Ресурсы ИНТЕРНЕТ для работников практического здравоохранения. Вопросы организации здравоохранения. 1999. № 1. C. 56-58.

13. Шахматова Т. Б., Тимонин А. Н. Инновационная деятельность и медицина. Патенты и лицензии. 2005. № 3. С. 46-49.

14. Bodnarchuk, O., Bodnarchuk, O., Ersozoglu, R., Kanishevska, L., Pet'ko, L., Turchynova, G., \& Vyshnivska, N. (2019). Model of Entrepreneurial Corporate Education and Prospects of Professional Development of Managers in Ukraine. Journal of Entrepreneurship Education, 22(2).

15. Sabat, N., Ersozoglu, R., Kanishevska, L., Pet'ko, L., Spivak, Y., Turchynova, G., \& Chernukha, N. (2019). Staff development as a condition for sustainable development entrepreneurship. Journal of Entrepreneurship Education, 22(1S)

16. Ternopilska V. I., Andruschenko V. I. Features of Formation of Future RadioElectronic Specialists' Technical Competence. Intellectual Archive. 2015. Volume 4. No. 6 (November). - Toronto : Shiny Word Corp., Canada. PP. 114-119. 